\title{
Seasonal heterogeneity in the photophysiological response to air exposure in two tropical intertidal seagrass species
}

\author{
K. Petrou ${ }^{1, *}$, I. Jimenez-Denness ${ }^{1}$, K. Chartrand ${ }^{2}$, C. McCormack ${ }^{2}$, \\ M. Rasheed ${ }^{2}$, P. J. Ralph ${ }^{1}$ \\ ${ }^{1}$ Plant Functional Biology and Climate Change Cluster and School of Environment, University of Technology, Sydney, \\ PO Box 123, Broadway, New South Wales 2007, Australia \\ ${ }^{2}$ Centre for Tropical Water \& Aquatic Ecosystem Research, James Cook University, PO Box 6811, Cairns, \\ Queensland 4870, Australia
}

\begin{abstract}
Photosynthesis, chlorophyll a fluorescence, leaf bio-optical properties and pigments were measured in 2 tropical intertidal seagrass species, Zostera muelleri ssp. capricorni and Halophila ovalis before, during and after air-exposure over a tidal cycle. Data were collected across 4 seasons (October and January - growing seasons; May and July — senescent seasons) to determine seasonal dynamics in physiological responses to air exposure. Both species showed clear light-dependent responses with a decline in photosynthetic efficiency and increased photoprotection during periods of combined maximum daily irradiance and air exposure for all seasons. In Z. muelleri ssp. capricorni there was a negative correlation between air-exposed effective quantum yield and light intensity, suggesting exposure was driving this decline. Conversely, sensitivity (decline in effective quantum yield of photosystem II) to increased irradiance dominated the response in $H$. ovalis, with no change in the magnitude of this response between air-exposed and submerged blades. The response to air exposure observed in $Z$. muelleri ssp. capricorni showed seasonal variation, with a greater decline in photosynthesis during the spring (October). Tidal exposure did not provide intertidal seagrasses a 'window' of photosynthetic respite (increase in photosynthesis) from high natural or anthropogenic turbidity. However, the periods immediately prior to and after exposure were important for providing an optimum period for net photosynthetic gain.
\end{abstract}

KEY WORDS: Seagrass · Zostera muelleri ssp. capricorni $\cdot$ Halophila ovalis $\cdot$ Chl a fluorescence Light-limitation $\cdot$ Air exposure

Resale or republication not permitted without written consent of the publisher

\section{INTRODUCTION}

Seagrass meadows are highly productive coastal habitats, important in nutrient cycling, carbon sequestering and supporting commercially valuable fisheries through the provision of habitat and food (Orth et al. 2006, Rasheed et al. 2008, Unsworth \& Cullen 2010). Globally, seagrass meadows occupy the coastal regions of tropical and temperate waters. Productivity of seagrasses, as with all plants, is driven by photosynthesis, which in turn is regulated by light, temperature and nutrient availability. In general, the minimum light requirement to maintain seagrass health (growth and photosynthesis) is relatively high (Duarte 1991, Dennison et al. 1993); however, tolerance to light deprivation often varies among species (Longstaff \& Dennison 1999).

Seagrass meadows that grow in the intertidal zone are exposed to highly variable and often extreme environmental conditions (Rasheed \& Unsworth 
2011, Taylor \& Rasheed 2011). Tidal oscillations that change asynchronously with diurnal irradiance mean that seagrasses are subject to large fluctuations in temperature and light. At times where the maximum irradiance and midday (air and water) temperature maximum coincide with low tide, intertidal seagrasses are vulnerable to thermal stress, desiccation and possible photosynthetic damage as a result of persistent photoinhibitory irradiances. Seagrasses need to constantly balance their use of captured photons for photosynthesis and the need for photoprotection from excess irradiance and other photosynthetic stress factors. This balance is achieved by adjusting their photosynthetic activity and pigments in response to light (Ralph 1998).

Light is considered the most important determinant of seagrass productivity, distribution and abundance (Dennison et al. 1993, Abal \& Dennison 1996). In many coastal habitats, light quantity and quality may change rapidly with increased light scattering and attenuation due to suspended particles, greatly altering light availability for seagrasses (Zimmerman et al. 1991, Longstaff \& Dennison 1999). Increased turbidity can result from natural processes such as storm events and tidal flux or catchment runoff after high rainfall. Additionally, it can be the result of anthropogenic activities such as poor land management practices leading to increased sediment loads in the coastal zone, or port and dredge operations that resuspend sediments, both causing significant light attenuation (Ralph et al. 2007).

Along the Queensland coast in Australia, many estuaries are naturally subject to large tidal fluxes and an associated constant re-suspension of sediment, creating a highly turbid light environment for intertidal seagrasses. Shallow seagrass meadows often become air-exposed during the day, altering photosynthetic condition and potentially affecting oxygen production (Johnston \& Raven 1986). Exposure or near-exposure at the lower tidal range may actually provide short periods of time for an increase in photosynthesis due to the increase in available light, or as a result of increased $\mathrm{CO}_{2}$ assimilation rates due to the decreased resistance for $\mathrm{CO}_{2}$ diffusion (Johnston \& Raven 1986, Beer \& Rehnberg 1997). In highly turbid conditions where plants are light-limited, periods of high light, while still submerged or air-exposed, may provide a 'window' of photosynthetic relief from high turbidity during low tide. Alternatively, if irradiances become too high or desiccation too prolonged during these periods it could lead to severe light stress on photosynthetic tissues and even damage the photosystems (Seddon
\& Cheshire 2001). It is also possible that exposed seagrass blades exceed their thermal tolerance for photosynthesis when exposed for long periods at low tide, which would also lead to a decline in net photosynthesis (Leuschner et al. 1998). Given the complex growing conditions that intertidal seagrasses are exposed to, it is necessary to understand how photosynthesis is impacted by the daily tidal cycle and periodic air exposure. The aim of this study was to determine whether this 'window' of exposure during a tidal cycle actually results in an increase in photosynthesis for these intertidal seagrasses living in turbid environments.

We investigated the effect of tidal flux on the photochemical efficiency, photoprotective pigment ratios and oxygen production of intertidal seagrass meadows from Gladstone Harbour over a tidal cycle across different seasons. Specifically, we measured changes in photosynthesis during exposure events to better understand how exposure and near-exposure (shallow water) influences seagrass physiology and production. We focused on 2 seagrass species whose distributions overlap on Australia's northeast coast; Halophila ovalis (R. Br.) Hook. $f$., a widespread tropical species, and Zostera muelleri ssp. capricorni (Ascherson), a species endemic to Australia that occurs only in shallow coastal tropical and sub-tropical waters. While this study is limited in its ability to provide significant causality to changes in photosynthesis upon exposure, the quarterly sampling does provide some understanding of the variability in the responses to air exposure in seagrasses over an annual cycle, and helps to differentiate possible effects of temperature stress, with lower water temperatures in the senescent season compared with the growing season.

\section{MATERIALS AND METHODS}

\section{Study site and sampling protocol}

The study site was an intertidal seagrass meadow at Pelican Banks, Gladstone Harbour, Australia $\left(23.766^{\circ} \mathrm{S}, 151.308^{\circ} \mathrm{E}\right)$, where 2 intertidal seagrass species Zostera muelleri ssp. capricorni and Halophila ovalis form the dominant benthic habitat. The seagrass meadows of Pelican Banks are subject to a semi-diurnal tidal cycle with 2 high and 2 low tides each day and an average spring tidal range of about $5 \mathrm{~m}$. Due to the tidal activity, the site is fairly turbid, particularly on the extreme of each incoming and outgoing tide. The maximum Nephelometric 
Turbidity Units (NTU) during the study months were 321.9 (October), 61.8 (January), 48.7 (May) and 21.45 (July) (data sourced from Vision Environment, QLD). Field measurements were made over 1 or 2 days on 4 separate field trips, each during different seasons spring (22 and 24 October 2010), summer (19 and 20 January 2011), autumn (14 May 2011) and winter (14 July 2011). Mean water temperatures for the months sampled were $23.69 \pm 1.14^{\circ} \mathrm{C}$ (October), $27.25 \pm$ $0.67^{\circ} \mathrm{C}$ (January), $21.45 \pm 1.52^{\circ} \mathrm{C}$ (May) and $18.18 \pm$ $0.59^{\circ} \mathrm{C}$ (July), while mean monthly solar irradiances were $12.30 \pm 7.12,6.56 \pm 2.56,5.76 \pm 3.50$ and $14.28 \pm$ 4.06 mol photons $\mathrm{m}^{-2} \mathrm{~d}^{-1}$ for the same months, respectively. Physiological measurements were made from before solar noon until sundown at nearhourly intervals starting $3 \mathrm{~h}$ prior to the absolute low tide. This sampling protocol was used to ensure that before, during and after air exposure photosynthetic activity was captured in the sampling program. Chlorophyll a (chl a) fluorescence measurements were performed using SCUBA divers to capture in situ photosynthetic activity; leaf samples (second blade) were collected by the divers and measurements including oxygen production and bio-optical properties were taken on board the vessel. Leaf blades were also collected and immediately frozen in liquid nitrogen for later HPLC pigment determinations of the state of the xanthophyll cycle.

\section{Chl a fluorescence}

Chl a fluorescence measurements were performed using a Pulse Amplitude Modulated fluorometer (Diving-PAM; Walz GmbH). Rapid light curves (RLCs) were measured on leaf blades using the inbuilt software routine of 9 incrementing actinic illumination steps $(0,33,72,117,178,249,375,512$, $780 \mu \mathrm{mol}$ photons $\mathrm{m}^{-2} \mathrm{~s}^{-1}$ ) at $10 \mathrm{~s}$ intervals. A specialised leaf clip was used to position the fibre optic probe at a fixed distance from the leaf blade for each measurement. All measurements were performed on the second leaf blade to be comparable across all plants. Six independent leaf blades were measured every 1 to $2 \mathrm{~h}$ on the outgoing and incoming tides, before, during and (where possible) after air exposure.

Relative electron transport rate ( $r$ ETR) was calculated as the product of effective quantum yield $\left(\Phi_{\text {PSII }}\right)$ and irradiance ( $\mu \mathrm{mol}$ photons $\mathrm{m}^{-2} \mathrm{~s}^{-1}$ ). Data were fitted according to the double exponential function as in Ralph \& Gademann (2005) and 3 photosynthetic parameters - maximum $r$ ETR $\left(r \mathrm{ETR}_{\max }\right)$, light utilisation efficiency $(\alpha)$ and minimum saturating irradiance $\left(E_{\mathrm{k}}\right)$ were derived from these curves. Initial effective quantum yield of PSII $\left(Y_{\mathrm{i}}\right)$ taken as the first $\Phi_{\text {PSII }}$ value $\left(\Phi_{\text {PSII }}\right.$ at in situ irradiance) from each RLC was plotted as a function of irradiance for both Halophila ovalis and Zostera muelleri ssp. capricorni to help differentiate a lightdependent from an exposure-dependent response, and a linear regression analysis was applied to the data.

\section{Direct $\mathrm{O}_{2}$ measurements}

Rates of photosynthesis were determined before, during and after exposure at low tide by measuring oxygen $\left(\mathrm{O}_{2}\right)$ evolution inside $5 \mathrm{ml}$ air- and water-tight incubation bottles equipped with oxygen sensitive luminescent material and read by an optical sensor (SDR SensorDish Reader, Presens). Leaves (second blade) were collected at 1 to $2 \mathrm{~h}$ intervals between 10:00 and 17:00 $\mathrm{h}$ on each of the sampling days and processed on board within 1 to $2 \mathrm{~h}$. Leaves were cleaned of epiphytes and placed into the incubation bottles filled with filtered (pore size $0.2 \mu \mathrm{m}$ ) seawater ( 3 to 5 leaves per bottle, $\mathrm{n}=6$ bottles). Oxygen concentrations within each bottle were measured at the start $\left(t_{0}\right)$ and end $\left(t_{1}\right)$ of a 20 min dark incubation period within a constant temperature seawater bath (same as the in situ temperature). After respiration measurements $\left(R_{\mathrm{D}}\right)$, the bottles were then placed into a transparent chamber that was returned to the seabed for $30 \mathrm{~min}$ of in situ light incubation, and recovered for measurement of the final $\mathrm{O}_{2}$ concentration $\left(t_{2}\right)$. Rates of gross oxygenic production $\left(P_{\mathrm{G}}\right)$ within each bottle were determined as: $P_{\mathrm{G}}=P_{\mathrm{N}}-R_{\mathrm{D}}$, where $P_{\mathrm{N}}$ and $R_{\mathrm{D}}$ are the net photosynthesis measured in the light and the respiration in the dark, respectively. Productivity was normalized to total leaf area in the bottle and reported as $\mu \mathrm{mol} \mathrm{O}_{2}$ $\mathrm{cm}^{-2} \mathrm{~h}^{-1}$.

\section{Leaf-specific absorptance}

Leaf-specific absorptance, $A(\lambda)$, is a measure of the fraction of photosynthetically active radiation (PAR) captured by the leaf's photosynthetic pigments. Leaf spectral transmittance and reflectance were measured from 400 to $750 \mathrm{~nm}$ at $1 \mathrm{~nm}$ resolution using 2 fibre optic spectrometers (USB2000+ and USB2000, Ocean Optics) interfaced with 2 integrating spheres (FOIS-1 and ISP-REF, Ocean Optics). Leaves col- 
lected from the seagrass meadow were placed in numbered plastic containers and kept moist and in the dark until optical properties were measured (within $\sim 1 \mathrm{~h}$ ). Leaves were gently scraped clean of epiphytes and placed between 2 microscope slides. Black tape was used to obscure the portion of the sample port not covered by leaf tissue.

For transmittance measurements, a tungsten halogen light source (LS-1, Ocean Optics) was adjusted to completely irradiate the $9.5 \mathrm{~mm}$ diameter sample port of the integrating sphere (FOIS-1). Leaf spectral transmittance $(T(\lambda))$ was calculated with reference to the slide and tape without a leaf in place. For reflectance measurements, the sample was placed over the port of the second integrating sphere (ISP-Ocean Optics) so that the same side faced the light source (internal to the sphere in the case of the ISP-Ocean Optics). Leaf spectral reflectance $(R(\lambda))$ was calculated, referenced to the slide and tape with a diffusive reflectance standard (Spectralon 98\%). $A(\lambda)$ was then calculated as:

$$
A(\lambda)=1-T(\lambda)-R(\lambda)-A(750 \mathrm{~nm})
$$

where $A(750 \mathrm{~nm})$ is a correction for non-photosynthetic absorptance:

$$
A(750 \mathrm{~nm})=1-T(750 \mathrm{~nm})-R(750 \mathrm{~nm})
$$

Leaf-specific photosynthetic absorptance $A \Phi$ (PAR) was calculated as the spectral average of $A(\lambda)$ over the spectral range $400-700 \mathrm{~nm}$ (Durako 2007).

\section{Leaf optical cross-section}

Leaf optical cross-section $a^{*}(\lambda)$ is a measure of chlorophyll use efficiency. The collected leaves were photographed and their surface area was determined digitally using image analysis software (ImageJ). Pigments were then extracted by grinding weighed leaf samples in ice-cold $80 \%$ acetone using a mortar and pestle with clean sand. Concentrations of chl $a$ and $\mathrm{chl} b$ were determined spectrophotometrically using the equations and extinction coefficients of Jeffrey \& Humphrey (1975). The leaf-specific absorption coefficient $a(\lambda)$ was calculated from $A(\lambda)$ as $-\ln [1-A(\lambda)]$ and $a^{*}(\lambda)$ was calculated by normalizing $a(\lambda)$ to the area-specific chl $a$ concentration (Enríquez 2005):

$$
a^{*}(\lambda)=a(\lambda) /[\mathrm{chl} a]
$$

\section{Photoprotective pigments}

Pigment concentrations were determined using HPLC. Pigments were extracted by grinding and analysed according to the methods of Van Heukelem \& Thomas (2001) with the only modification being an extra filtration step through $0.2 \mu \mathrm{m}$ PTFE $13 \mathrm{~mm}$ syringe filters (Micro-Analytix). Clarified samples were stored in amber HPLC glass vials (Waters Australia) at $-80^{\circ} \mathrm{C}$ overnight before analysis. The HPLC system included a pump, temperature-controlled auto-injector (Waters Australia), C8 column $(150 \times 4.6 \mathrm{~mm}$; Eclipse XDB), and photodiode array detector (Waters Australia). Pigments were identified by comparison of their retention times and spectra using calibration standards (DHI) for each pigment. Peaks were integrated using curve-fitting software (Empower Pro, Waters Australia) and checked manually to confirm the accuracy of the peak baselines and the similarity of the integrated peaks to that of the standard. The pigment data were used to investigate rapid photoprotective responses over a tidal cycle by measuring the de-epoxidation state of violaxanthin (a measure of violaxanthin conversion to the photoprotective zeaxanthin). This was calculated as: [(zeaxanthin) + $(0.5 \times$ antheraxanthin) $]$ / (violaxanthin + antheraxanthin + zeaxanthin (Thayer \& Björkman 1990).

\section{Underwater light climate}

Down-welling PAR at the water-surface and seafloor were measured at each sampling period using a $2 \Pi$ underwater quantum sensor (LI192SA, LI-COR) attached to a frame and a photometer (LI-1400, LI-COR). Water depth was also measured at each time point of sampling.

\section{Data analysis}

To test for significant differences in the photosynthetic parameters and oxygen production throughout the tidal cycle, a 1-way ANOVA was used and pairwise comparisons made using a Tukey's post hoc test. To ensure that the assumption of equal variances for all parametric tests was satisfied, a Levene's test was applied to all data a priori. In cases where this assumption was not met, data were log-transformed before analysis or a non-parametric Kruskal-Wallis test was used instead. Results were considered statistically significant at $p<0.05$. All analyses were performed using Minitab statistical software (v.15.1.0.0). 


\section{RESULTS}

\section{Spring (growing season)}

Maximum daily irradiance coincided with the time just prior to air exposure on both sampling days, but stayed around the same intensity (543-733 $\mu \mathrm{mol}$ photons $\mathrm{m}^{-2} \mathrm{~s}^{-1}$ ) during the exposure event (Fig. 1a,b). Due to the nature of the measurements, oxygen data could only be measured in water (as the instrument relies on aqueous phase). Therefore, samples were taken immediately prior to exposure and after $1 \mathrm{~h}$ of complete air exposure. Oxygen production showed a significant decrease after exposure in Zostera muelleri ssp. capricorni $(\mathrm{p}<0.05$; Fig. 1c). The same response was measured in Halophila ovalis, whereby $\mathrm{O}_{2}$ production following air exposure was significantly lower than during the immersed periods $(\mathrm{p}<$ 0.05 ; Fig. 1d). Seagrass $a^{*}(\lambda)$ remained constant for $Z$. muelleri ssp. capricorni and $H$. ovalis $(0.62 \pm 0.12$, $0.46 \pm 0.09$, respectively) throughout the tidal exposure event. The photoprotective pigment ratios determined by HPLC showed a strong and significant increase $(p<0.001)$ with increased irradiance, where the violaxanthin de-epoxidation state increased throughout the day in both $Z$. muelleri ssp. capricorni

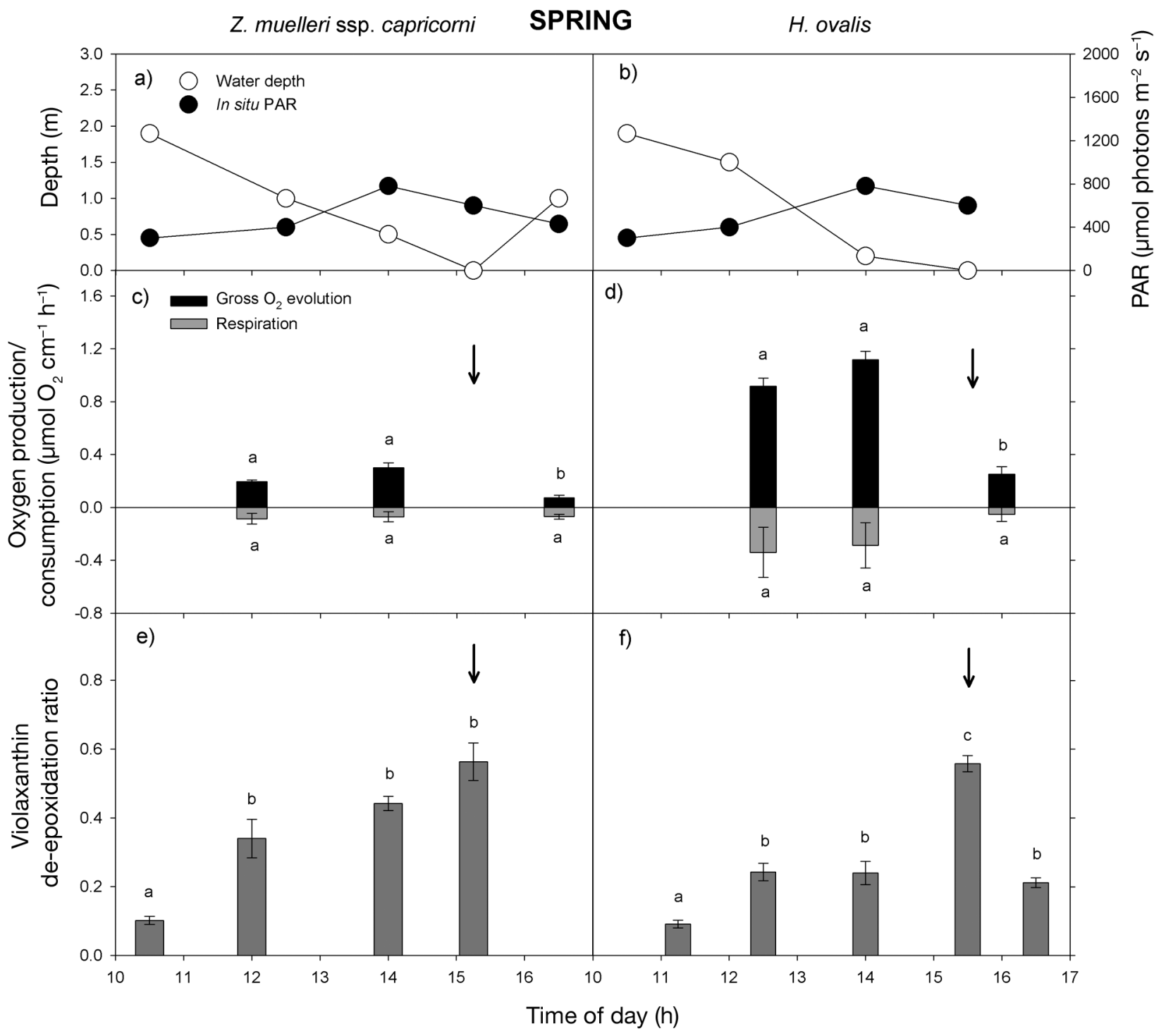

Fig. 1. Zostera muelleri ssp. capricorni and Halophila ovalis. $(\mathrm{a}, \mathrm{b})$ Photosynthetically active radiation (PAR) at the depth of the seagrass and water depth over the spring tidal cycles; $(\mathrm{c}, \mathrm{d})$ mean $( \pm \mathrm{SE})$ in situ gross oxygenic photosynthesis and dark respiration; $(\mathrm{e}, \mathrm{f})$ mean $( \pm \mathrm{SE})$ violaxanthin de-epoxidation ratio during tidal cycles on (e) 22 October and (f) 24 October 2010 . $(\mathrm{c}-\mathrm{f}) \mathrm{n}=6$; different letters above bars indicate significant differences (Tukey's, $\mathrm{p}<0.05$ ); arrows indicate time of air exposure at low tide 
and $H$. ovalis (Fig. 1e,f). On both days, the greatest violaxanthin de-epoxidation occurred during air exposure (black arrows) in both species (Fig. 1e,f).

$Y_{\mathrm{i}}$ from the RLC declined significantly $(\mathrm{p}<0.001)$ with increased irradiance from 10:30 to $14: 00 \mathrm{~h}$ in Zostera muelleri ssp. capricorni with a further significant decline occurring during air exposure (Table 1). The same pattern was seen in Halophila ovalis with a consistent decline in $Y_{\mathrm{i}}$ with increasing in situ irradiance; however, only a significant drop $(\mathrm{p}<0.001)$ in $Y_{\mathrm{i}}$ occurred during exposure, $r \mathrm{ETR}_{\max }$ and $E_{\mathrm{k}}$ values showed a light-dependent response in both species, with a significant increase in $r \mathrm{ETR}_{\max }$ with increased irradiance followed by a significant decline upon air exposure in both $Z$. muelleri ssp. capricorni $(\mathrm{p}<$ $0.001)$ and $H$. ovalis $(\mathrm{p}=0.011)$. $E_{\mathrm{k}}$ was significantly greater at the maximum daily irradiance for both $Z$. muelleri ssp. capricorni $(p=0.001)$ and $H$. ovalis $(p=0.003)$. These changes in photosynthetic parameters further support the idea of additional stress to the plants when exposed, where seagrass, able to maintain high rates of electron transport at higher irradiance levels only seem to be able to do this if they are submerged. $\alpha$ decreased throughout the day in Z. muelleri ssp. capricorni, declining with increased irradiance and dropped significantly as the plants became air-exposed $(\mathrm{p}<0.001)$. A similar pattern was seen in $H$. ovalis $(\mathrm{p}=0.001)$, where increased irradiance lead to a decline in $\alpha$. However, unlike $Z$. muelleri ssp. capricorni, there was no difference in $\alpha$ from the highest irradiance to being exposed, suggesting that the plant's ability to efficiently utilise the light available is not greatly impacted by air-exposed conditions, and that in $H$. ovalis this parameter is more sensitive to high irradiance than air-exposed conditions.

\section{Summer (growing season)}

In situ PAR varied throughout the day due to intermittent cloud cover. However, it was maximal during tidal minimum on 19 January, with plants being airexposed during irradiances above $1600 \mu \mathrm{mol}$ photons $\mathrm{m}^{-2} \mathrm{~s}^{-1}$ (Fig. 2a, Table 2). On 20 January, PAR reached a maximum $1 \mathrm{~h}$ prior to exposure, but remained above $1000 \mu \mathrm{mol}$ photons $\mathrm{m}^{-2} \mathrm{~s}^{-1}$ during the exposure event (Fig. 2b, Table 2). Oxygen production in Zostera muelleri ssp. capricorni increased significantly with increasing irradiance as the tide withdrew (Fig. 2c). Gross $\mathrm{O}_{2}$ evolution just prior to air exposure was 2 to 3 times greater than the noon values measured at $\sim 1 \mathrm{~m}$ depth. The reduced light level at the end of the day may have contributed to the decline in photosynthesis after re-immersion for $Z$. muelleri ssp. capricorni following air exposure (Fig. 2c). For Halophila ovalis, gross $\mathrm{O}_{2}$ production rates did not vary throughout the tidal cycle. There was, however, a significant decline in respiration rate at $14: 00 \mathrm{~h}$ (Fig. 2d). Seagrass $a^{*} \lambda$ remained largely constant throughout the tidal exposure event $(0.48 \pm 0.04$, $0.46 \pm 0.09$, respectively). There was a significant increase $(p<0.001)$ in the violaxanthin de-epoxidation state with increased irradiance (Fig. 2e,f). In Z. muelleri ssp. capricorni the greatest violaxanthin de-epoxidation occurred during air exposure (black arrows). A similar response was measured in $H$. ovalis; however, the last time point did not drop following air exposure (Fig. 2f).

There was a significant decline $(\mathrm{p}<0.005)$ in $Y_{\mathrm{i}}$ during air exposure in Zostera muelleri ssp. capricorni and Halophila ovalis (Table 2). $r \mathrm{ETR}_{\max }$ and $E_{\mathrm{k}}$ values showed a light-dependent response in both species, although with some inconsistencies for $Z$.

Table 1. Zostera muelleri ssp. capricorni and Halophila ovalis. Photosynthetic parameters initial effective quantum yield of photosystem II $\left(Y_{\mathrm{i}}\right)$, relative maximum electron transport rate $\left(r \mathrm{ETR}_{\max }\right)$, minimum saturating irradiance $\left(E_{\mathrm{k}}\right)$ and light utilisation efficiency $(\alpha)$ calculated from the rapid light curves of 2 seagrass species in spring. PAR and $E_{\mathrm{k}}$ are in $\mu$ mol photons $\mathrm{m}^{-2} \mathrm{~s}^{-1}$. Data are mean $\pm \mathrm{SD}(\mathrm{n}=6)$. Different superscript letters indicate significant differences $($ Tukey's, $\mathrm{p}<0.05)$

\begin{tabular}{|lcccccc|}
\hline \multicolumn{2}{l}{ Time $(\mathrm{h})$} & PAR & Water depth $(\mathrm{m})$ & $Y_{\mathrm{i}}$ & $r \mathrm{ETR}_{\max }$ & $E_{\mathrm{k}}$ \\
\hline \multicolumn{2}{l}{ Zostera muelleri ssp. capricorni } & & & & $\alpha$ \\
$10: 30$ & $240-320$ & 1.9 & $0.726 \pm 0.010^{\mathrm{a}}$ & $69.90 \pm 4.800^{\mathrm{ab}}$ & $70.90 \pm 5.400^{\mathrm{a}}$ & $0.980 \pm 0.020^{\mathrm{a}}$ \\
$12: 00$ & $358-510$ & 1.5 & $0.702 \pm 0.020^{\mathrm{a}}$ & $84.04 \pm 7.330^{\mathrm{bc}}$ & $97.70 \pm 9.020^{\mathrm{bc}}$ & $0.860 \pm 0.020^{\mathrm{b}}$ \\
$14: 00$ & $792-774$ & 0.2 & $0.647 \pm 0.026^{\mathrm{b}}$ & $84.90 \pm 12.20^{\mathrm{c}}$ & $108.3 \pm 27.40^{\mathrm{b}}$ & $0.820 \pm 0.110^{\mathrm{b}}$ \\
$15: 40$ & $733-543$ & Exposed & $0.598 \pm 0.036^{\mathrm{c}}$ & $55.05 \pm 11.90^{\mathrm{a}}$ & $79.90 \pm 7.880^{\mathrm{c}}$ & $0.680 \pm 0.130^{\mathrm{c}}$ \\
Halophila ovalis & & & & & \\
$10: 30$ & $240-320$ & 1.9 & $0.737 \pm 0.020^{\mathrm{a}}$ & $69.60 \pm 13.20^{\mathrm{a}}$ & $69.00 \pm 15.40^{\mathrm{a}}$ & $1.000 \pm 0.040^{\mathrm{a}}$ \\
$12: 00$ & $358-510$ & 1.5 & $0.673 \pm 0.014^{\mathrm{a}}$ & $74.80 \pm 12.75^{\mathrm{ab}}$ & $79.40 \pm 18.60^{\mathrm{a}}$ & $0.960 \pm 0.090^{\mathrm{a}}$ \\
$14: 00$ & $792-774$ & 0.2 & $0.657 \pm 0.081^{\mathrm{a}}$ & $91.10 \pm 16.80^{\mathrm{b}}$ & $113.0 \pm 21.50^{\mathrm{bc}}$ & $0.810 \pm 0.028^{\mathrm{b}}$ \\
$15: 40$ & $733-543$ & Exposed & $0.549 \pm 0.102^{\mathrm{b}}$ & $84.50 \pm 15.60^{\mathrm{ac}}$ & $84.50 \pm 15.60^{\mathrm{ac}}$ & $0.770 \pm 0.080^{\mathrm{b}}$ \\
\hline
\end{tabular}




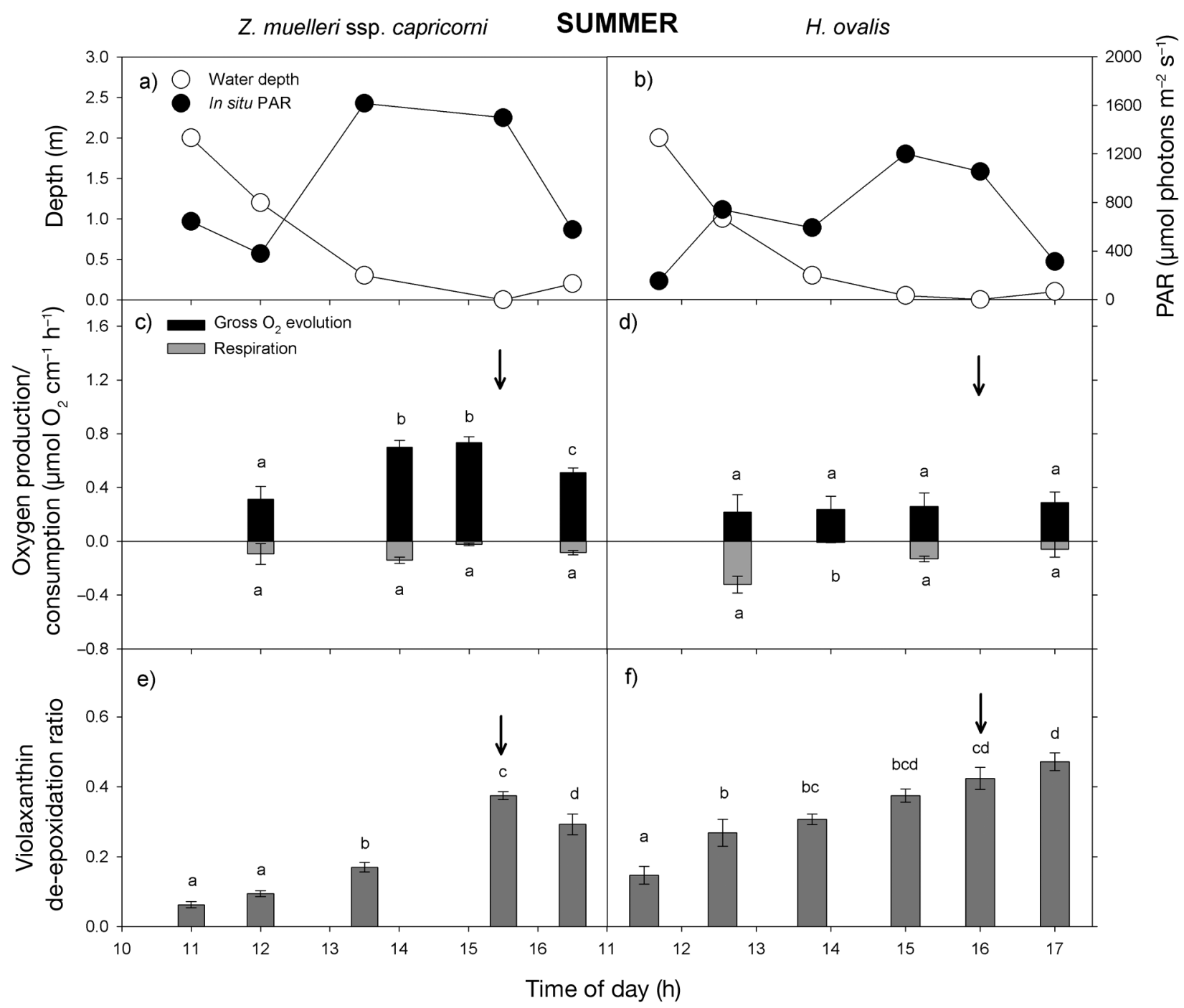

Fig. 2. Zostera muelleri ssp. capricorni and Halophila ovalis. (a,b) PAR at the depth of the seagrass and water depth over summer tidal cycles; $(\mathrm{c}, \mathrm{d})$ mean $( \pm \mathrm{SE})$ in situ gross oxygenic photosynthesis and dark respiration; $(\mathrm{e}, \mathrm{f})$ mean $( \pm \mathrm{SE})$ violaxanthin de-epoxidation ratio. ( $\mathrm{c}-\mathrm{f}) \mathrm{n}=6$; different letters above bars indicate significant differences (Tukey's, $\mathrm{p}<0.05$ ); arrows indicate time of air exposure at low tide

muelleri ssp. capricorni. These were likely due to the intermittent cloud cover during sampling which may have affected some of the fluorescence and PAR values. In both species there was a significant decline in $r \mathrm{ETR}_{\max }$ during air exposure $(\mathrm{p}<0.001)$. In both cases, irradiance was equally high immediately prior to and during air exposure, further supporting the suggestion of additional stress to the plants when exposed to desiccation, even when irradiance is optimal for greater rates of electron transport. $\alpha$ decreased throughout the day in both $Z$. muelleri ssp. capricorni and $H$. ovalis, declining with increased irradiance and then declining further as the plants became air-exposed $(p<0.001)$. The significant re- covery in $\alpha$ following exposure emphasises the negative impact that air exposure has on the photosynthetic efficiency of $Z$. muelleri ssp. capricorni.

\section{Autumn (senescent season)}

The low tide (13:00 h) coincided with the maximum solar irradiance during the autumn study, with PAR reaching in excess of $1800 \mu \mathrm{mol}$ photons $\mathrm{m}^{-2} \mathrm{~s}^{-1}$ during air exposure (Fig. 3a,b). Consistent with the previous tidal exposure studies, rates of gross $\mathrm{O}_{2}$ production in both species were significantly greater $(\mathrm{p}<0.01$ ) at $12: 30 \mathrm{~h}$ (just prior to air exposure) than at 
Table 2. Zostera muelleri ssp. Capricorni and Halophila ovalis. Photosynthetic parameters calculated from the rapid light curves of Z. muelleri ssp. capricorni and H. ovalis in summer. Data are mean \pm SD $(n=6)$. See Table 1 for details. Different superscript letters indicate significant differences (Tukey's, $\mathrm{p}<0.05$ )

\begin{tabular}{|c|c|c|c|c|c|c|}
\hline Time (h) & PAR & Water depth (m) & $Y_{\mathrm{i}}$ & $r \mathrm{ETR}_{\max }$ & $E_{\mathrm{k}}$ & $\alpha$ \\
\hline \multicolumn{7}{|c|}{ Zostera muelleri ssp. capricorni } \\
\hline 11:00 & 400 & 2.5 & $0.773 \pm 0.010^{\mathrm{a}}$ & $40.27 \pm 3.160^{\mathrm{a}}$ & $99.49 \pm 8.360^{\mathrm{a}}$ & $0.410 \pm 0.010^{\mathrm{a}}$ \\
\hline $12: 00$ & 86 & 1 & $0.737 \pm 0.042^{\mathrm{a}}$ & $28.62 \pm 5.300^{\mathrm{b}}$ & $74.06 \pm 12.39^{b}$ & $0.380 \pm 0.030^{\mathrm{a}}$ \\
\hline $13: 30$ & 1150 & 0.3 & $0.730 \pm 0.030^{\mathrm{a}}$ & $37.48 \pm 3.510^{\mathrm{a}}$ & $102.7 \pm 9.130^{\mathrm{a}}$ & $0.360 \pm 0.030^{\mathrm{a}}$ \\
\hline $15: 00$ & 1692 & Exposed & $0.346 \pm 0.081^{\mathrm{b}}$ & $10.65 \pm 3.030^{\mathrm{c}}$ & $60.52 \pm 13.58^{\mathrm{b}}$ & $0.170 \pm 0.030^{b}$ \\
\hline $16: 30$ & 320 & 0.2 & $0.607 \pm 0.080^{\mathrm{a}}$ & $37.41 \pm 7.750^{\mathrm{ab}}$ & $130.8 \pm 23.82^{\mathrm{c}}$ & $0.280 \pm 0.040^{\mathrm{c}}$ \\
\hline \multicolumn{7}{|c|}{ Halophila ovalis } \\
\hline $11: 30$ & 153 & 2 & $0.759 \pm 0.022^{\mathrm{a}}$ & $15.64 \pm 2.590^{\mathrm{a}}$ & $36.70 \pm 6.190^{\mathrm{a}}$ & $0.430 \pm 0.060^{\mathrm{a}}$ \\
\hline $12: 30$ & 741 & 1 & $0.741 \pm 0.018^{\mathrm{a}}$ & $26.82 \pm 4.960^{\mathrm{ab}}$ & $61.86 \pm 13.52^{\mathrm{b}}$ & $0.440 \pm 0.020^{\mathrm{a}}$ \\
\hline $13: 45$ & 591 & 0.6 & $0.734 \pm 0.017^{\mathrm{a}}$ & $28.17 \pm 8.170^{\mathrm{b}}$ & $69.22 \pm 23.03^{b}$ & $0.410 \pm 0.030^{\mathrm{a}}$ \\
\hline $15: 00$ & 1200 & 0.05 & $0.614 \pm 0.076^{\mathrm{a}}$ & $42.20 \pm 13.95^{\mathrm{b}}$ & $145.1 \pm 46.89^{\mathrm{c}}$ & $0.310 \pm 0.030^{\mathrm{b}}$ \\
\hline 16:00 & 1053 & Exposed & $0.436 \pm 0.053^{\mathrm{b}}$ & $14.74 \pm 5.910^{\mathrm{ca}}$ & $69.34 \pm 31.91^{\mathrm{ab}}$ & $0.220 \pm 0.030^{\mathrm{c}}$ \\
\hline
\end{tabular}

10:10 and 14:10 h (Fig. 3c,d). No change in dark respiration rate was found throughout the day in either species. During this collection trip, Zostera muelleri ssp. capricorni and Halophila ovalis were sampled on the same day and therefore incubated simultaneously, thus being exposed to identical light and temperature conditions. Interestingly, $\mathrm{O}_{2}$ production rate appears more responsive to irradiance variations and air exposure in $Z$. muelleri ssp. capricorni than in H. ovalis (Fig. 3c,d), closely matching the chl a fluorescence data. In line with previous measurements, the fraction of light absorbed by seagrass leaves remained constant throughout the tidal cycle $(0.46 \pm$ $0.01,0.49 \pm 0.03$, respectively), thus further confirming that these seagrasses do not regulate their lightcapturing efficiency under rapidly changing light intensities. Also consistent with the previous 2 seasons, the violaxanthin de-epoxidation state showed a significant increase in de-epoxidation ratio with increased irradiance $(\mathrm{p}<0.001)$ and maximum de-epoxidation occurring during air exposure (Fig. 3e,f).

$Y_{\mathrm{i}}$ declined significantly $(\mathrm{p}<0.001)$ during air exposure and greatest irradiance in both species (Table 3 ), but with a greater decline measured for Zostera muelleri ssp. capricorni. A similar pattern was observed for $r \mathrm{ETR}_{\max }$ and $\alpha$ in $Z$. muelleri ssp. capricorni declining significantly during air exposure $(\mathrm{p}=0.012$ and $\mathrm{p}=$ 0.001 ), but recovering by 14:10 h. Halophila ovalis did not show the same trend in photosynthetic parameters. Instead, significant differences were only detected for $r \mathrm{ETR}_{\max }$ at the lowest irradiance levels and deepest depth $(08: 30 \mathrm{~h})$, where $r \mathrm{ETR}_{\max }$ was greatest $(\mathrm{p}<0.047)$ and during moderate light at $10: 10 \mathrm{~h}$ where $r \mathrm{ETR}_{\max }$ dropped significantly $(\mathrm{p}=0.038)$. Thus, it would seem that there was no clear response in $r \mathrm{ETR}_{\max }$ to air exposure or irradiance in autumn for $H$. ovalis. No differences were detected in $E_{\mathrm{k}}$ or $\alpha$ between sampling times for $H$. ovalis, also indicating no light-dependent response or sensitivity to desiccation.

\section{Winter (senescent season)}

Due to poor weather conditions, only one day of sampling was possible for this season. Therefore, data was only collected for Zostera muelleri ssp. capricorni for the winter period. Tidal and PAR data showed an inverse pattern, consistent with previous seasons, of high irradiance during low tide (Fig. 4a). Unlike previous seasons, however, oxygen production declined significantly $(\mathrm{p}<0.05)$ just before air exposure and then stayed low following exposure (Fig. 4b). This would suggest that the decline in photosynthesis was due to high irradiance and not necessarily air exposure, as was seen in the previous 3 seasons. Seagrass photosynthetic light absorption capacity remained constant throughout the tidal exposure event $(0.45 \pm 0.01)$. Consistent with the other seasons, violaxanthin de-epoxidation state showed a significant increase in de-epoxidation ratio with increased irradiance $(p<0.001)$, with maximum deepoxidation occurring during air exposure (Fig. 4c). $Y_{\mathrm{i}}, r \mathrm{ETR}_{\max }$ and $\alpha$ all declined significantly $(\mathrm{p}<0.05)$ during air exposure (Table 4), but did not differ during the other parts of the day and there was no significant change in $E_{\mathrm{k}}$ throughout the day.

\section{Light-dependent or air-exposed response?}

To help differentiate a light-dependent response from the effects of air exposure, $Y_{\mathrm{i}}$ as a function of in 


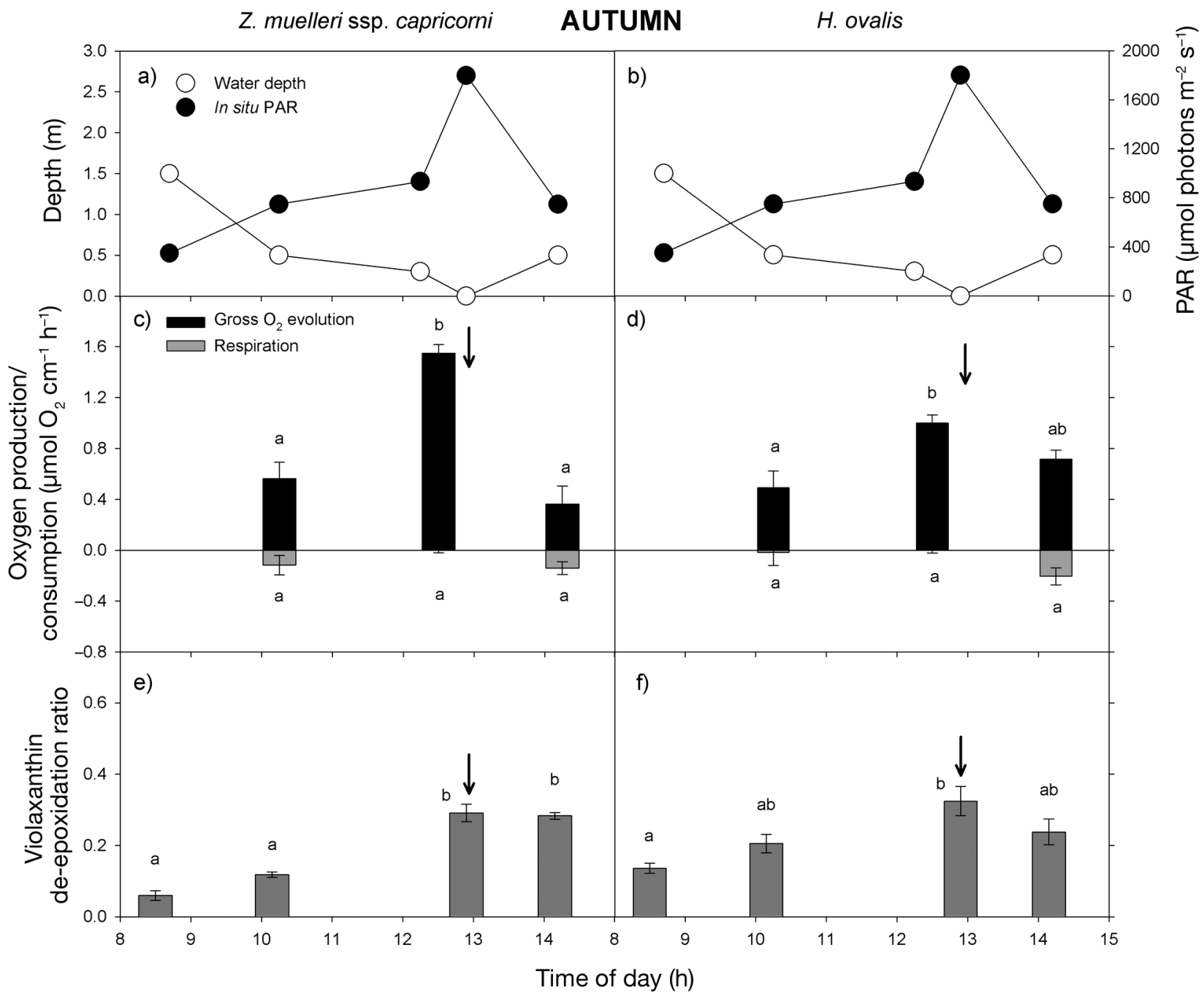

Fig. 3. Zostera muelleri ssp. capricorni and Halophila ovalis. $(\mathrm{a}, \mathrm{b}) \mathrm{PAR}$ at the depth of the seagrass and water depth over an autumn tidal cycle; $(\mathrm{c}, \mathrm{d})$ mean $( \pm \mathrm{SE})$ in situ gross oxygenic photosynthesis and dark respiration $(\mathrm{e}, \mathrm{f})$ mean $( \pm \mathrm{SE})$ violaxanthin de-epoxidation ratio. ( $\mathrm{c}-\mathrm{f}) \mathrm{n}=6(\mathrm{Z}$. muelleri); $\mathrm{n}=4(\mathrm{H}$. ovalis), different letters above bars indicate significant differences

(Tukey's, $\mathrm{p}<0.05$ ); arrows indicate time of air exposure at low tide

Table 3. Zostera muelleri ssp. capricorni and Halophila ovalis. Photosynthetic parameters calculated from the rapid light curves of 2 seagrasses in autumn. Data are mean $\pm \mathrm{SD}(\mathrm{n}=6, Z$. muelleri; $\mathrm{n}=4, H$. ovalis). See Table 1 for details. Different superscript letters indicate significant differences (Tukey's, $\mathrm{p}<0.05$ )

\begin{tabular}{|lcccccc|}
\hline \multicolumn{2}{l}{ Time $(\mathrm{h})$} & PAR & Water depth $(\mathrm{m})$ & $Y_{\mathrm{i}}$ & $r \mathrm{ETR}_{\max }$ & $E_{\mathrm{k}}$ \\
\hline \multicolumn{2}{l}{ Zostera muelleri ssp. capricorni } & & & & \\
$08: 30$ & 350 & 1.5 & $0.749 \pm 0.019^{\mathrm{a}}$ & $71.84 \pm 15.23^{\mathrm{a}}$ & $78.79 \pm 18.61^{\mathrm{a}}$ & $0.916 \pm 0.041^{\mathrm{a}}$ \\
$10: 10$ & 750 & 0.5 & $0.732 \pm 0.034^{\mathrm{a}}$ & $67.79 \pm 21.24^{\mathrm{a}}$ & $73.04 \pm 25.86^{\mathrm{a}}$ & $0.937 \pm 0.040^{\mathrm{a}}$ \\
$13: 00$ & 1800 & Exposed & $0.535 \pm 0.070^{\mathrm{b}}$ & $37.69 \pm 9.798^{\mathrm{b}}$ & $58.63 \pm 17.16^{\mathrm{a}}$ & $0.674 \pm 0.194^{\mathrm{b}}$ \\
$14: 10$ & 750 & 0.5 & $0.719 \pm 0.050^{\mathrm{a}}$ & $67.74 \pm 22.23^{\mathrm{a}}$ & $83.23 \pm 26.48^{\mathrm{a}}$ & $0.812 \pm 0.067^{\mathrm{a}}$ \\
Halophila ovalis & & & & & \\
$08: 30$ & 350 & 1.5 & $0.723 \pm 0.022^{\mathrm{a}}$ & $82.24 \pm 21.30^{\mathrm{a}}$ & $86.61 \pm 23.21^{\mathrm{a}}$ & $0.954 \pm 0.062^{\mathrm{a}}$ \\
$10: 10$ & 750 & 0.5 & $0.638 \pm 0.100^{\mathrm{ab}}$ & $40.82 \pm 15.54^{\mathrm{b}}$ & $44.41 \pm 15.13^{\mathrm{a}}$ & $0.921 \pm 0.619^{\mathrm{a}}$ \\
$13: 00$ & 1800 & Exposed & $0.609 \pm 0.072^{\mathrm{b}}$ & $51.92 \pm 15.21^{\mathrm{b}}$ & $60.56 \pm 24.51^{\mathrm{a}}$ & $0.888 \pm 0.112^{\mathrm{a}}$ \\
$14: 10$ & 750 & 0.5 & $0.733 \pm 0.033^{\mathrm{a}}$ & $53.15 \pm 21.90^{\mathrm{b}}$ & $54.04 \pm 22.75^{\mathrm{a}}$ & $0.978 \pm 0.114^{\mathrm{a}}$ \\
\hline
\end{tabular}


situ irradiance was plotted for Zostera muelleri ssp. capricorni and Halophila ovalis (Fig. 5). Regression analyses were then performed on the data to ascertain the effect of air exposure on $Y_{\mathrm{i}}$. First, a regression analysis using all the $Y_{\mathrm{i}}$ data was performed to

\section{Z. muelleri ssp. capricorni WINTER}

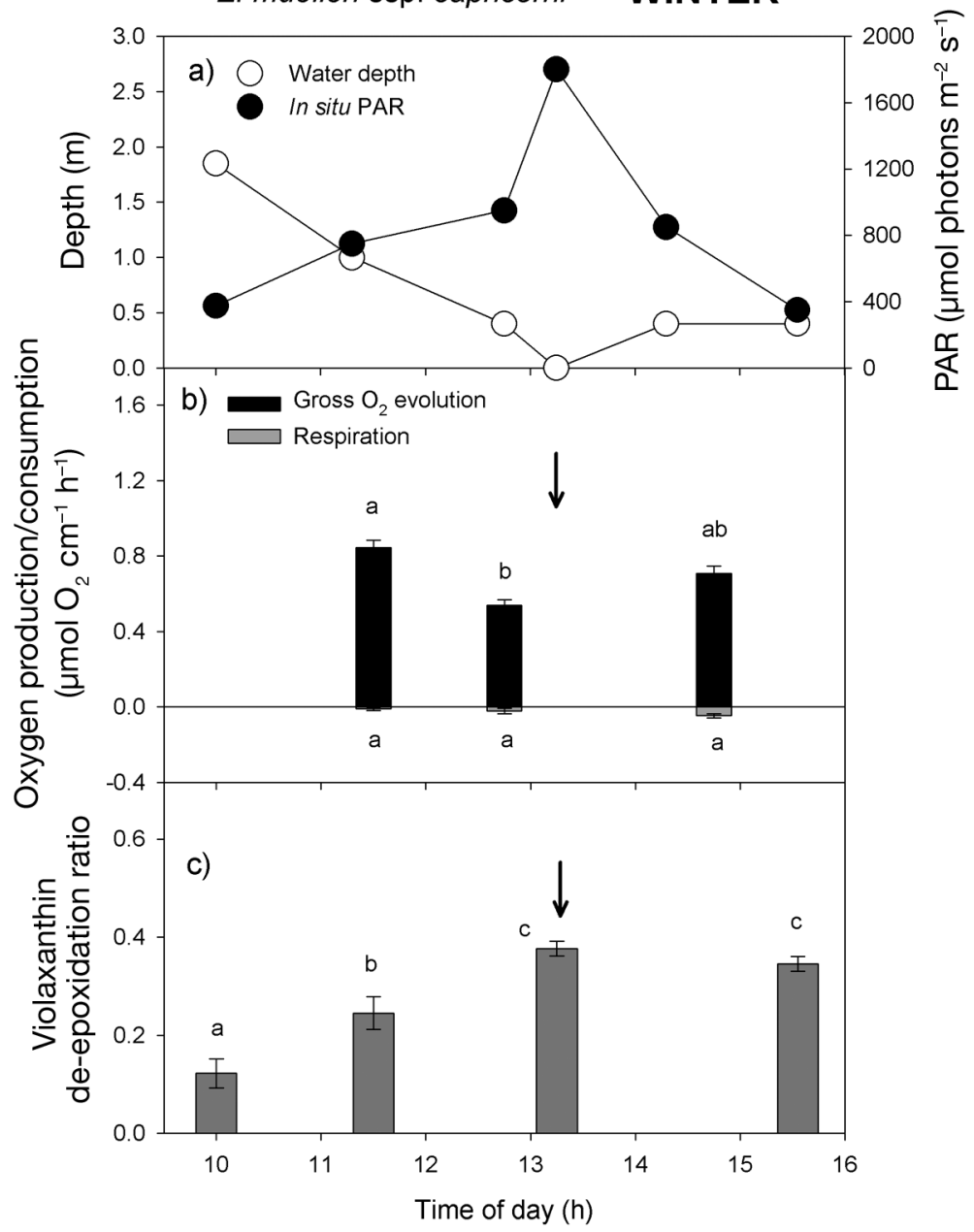

Fig. 4. Zostera muelleri ssp. capricorni. (a) PAR at the depth of the seagrass and water depth over a winter tidal cycle; (b) mean $( \pm \mathrm{SE})$ in situ gross oxygenic photosynthesis and dark respiration; (c) mean $( \pm \mathrm{SE})$ violaxanthin de-epoxidation ratio. $\mathrm{n}=6$; different letters above bars indicate significant differences (Tukey's, $\mathrm{p}<0.05$ ); down arrows indicate time of air exposure at low tide elucidate the effect of light on $Y_{\mathrm{i}}$ (Fig. 5a,c). Then another regression using only the $Y_{\mathrm{i}}$ values obtained while seagrass were submerged (i.e. in the absence of air-exposed data) was conducted to see if this altered the light-dependent response (Fig. 5b,d). $Y_{\mathrm{i}}$ for Z. muelleri ssp. capricorni showed a significant although weak negative correlation with increased irradiance $\left(\mathrm{R}^{2}=\right.$ $0.3268, \mathrm{p}<0.0001)$ when regression was applied to all the data (including the airexposed data; Fig. 5a). However, when only the submerged data were used (Fig. 5b), no correlation was detected $\left(\mathrm{R}^{2}=\right.$ 0.0001). In contrast, a significant relationship was detected in $H$. ovalis between $Y_{\mathrm{i}}$ and irradiance under both airexposed $\left(R^{2}=0.4872, p<0.0001\right.$; Fig. 5c) and submerged conditions $\left(\mathrm{R}^{2}=0.3313\right.$, $\mathrm{p}<0.0001$; Fig. 5d).

\section{DISCUSSION}

All organisms growing in an intertidal habitat must tolerate oscillations in environmental conditions, some of which may act synergistically or antagonistically. Consequently, trying to ascertain the effect of a single environmental stressor is difficult in isolation of other environmental factors (Lee et al. 2007). For this reason, this study was focused on determining whether there was a significant change in photosynthesis over a tidal cycle, with particular interest in determining how photosynthesis was impacted by low tide exposure (not on what was the main driver of this change). Several significant differences in physiological responses were detectable in both seagrass species and between seasons. The data show that oxygen evolution increased as the tide receded and then declined significantly immediately after

Table 4. Zostera muelleri ssp. capricorni. Photosynthetic parameters calculated from the light response curves of $Z$. muelleri in winter. Data are mean \pm SD $(n=6)$. See Table 1 for details. Different superscript letters indicate significant differences (Tukey's, p <0.05)

\begin{tabular}{|lcccccc|}
\hline Time $(\mathrm{h})$ & PAR & Water depth $(\mathrm{m})$ & $Y_{\mathrm{i}}$ & $r \mathrm{ETR}_{\max }$ & $E_{\mathrm{k}}$ & $\alpha$ \\
\hline $10: 00$ & 400 & 1.8 & $0.736 \pm 0.017^{\mathrm{a}}$ & $92.77 \pm 45.17^{\mathrm{a}}$ & $101.3 \pm 57.37^{\mathrm{a}}$ & $0.939 \pm 0.086^{\mathrm{a}}$ \\
$11: 30$ & 800 & 1 & $0.712 \pm 0.023^{\mathrm{a}}$ & $105.6 \pm 27.56^{\mathrm{a}}$ & $121.0 \pm 41.12^{\mathrm{a}}$ & $0.894 \pm 0.082^{\mathrm{a}}$ \\
$13: 15$ & 1800 & Exposed & $0.558 \pm 0.049^{\mathrm{b}}$ & $57.40 \pm 12.39^{\mathrm{b}}$ & $75.15 \pm 18.77^{\mathrm{a}}$ & $0.776 \pm 0.095^{\mathrm{b}}$ \\
$15: 35$ & 350 & 0.4 & $0.694 \pm 0.036^{\mathrm{a}}$ & $92.64 \pm 23.72^{\mathrm{a}}$ & $107.3 \pm 30.89^{\mathrm{a}}$ & $0.871 \pm 0.055^{\mathrm{ab}}$ \\
\hline
\end{tabular}




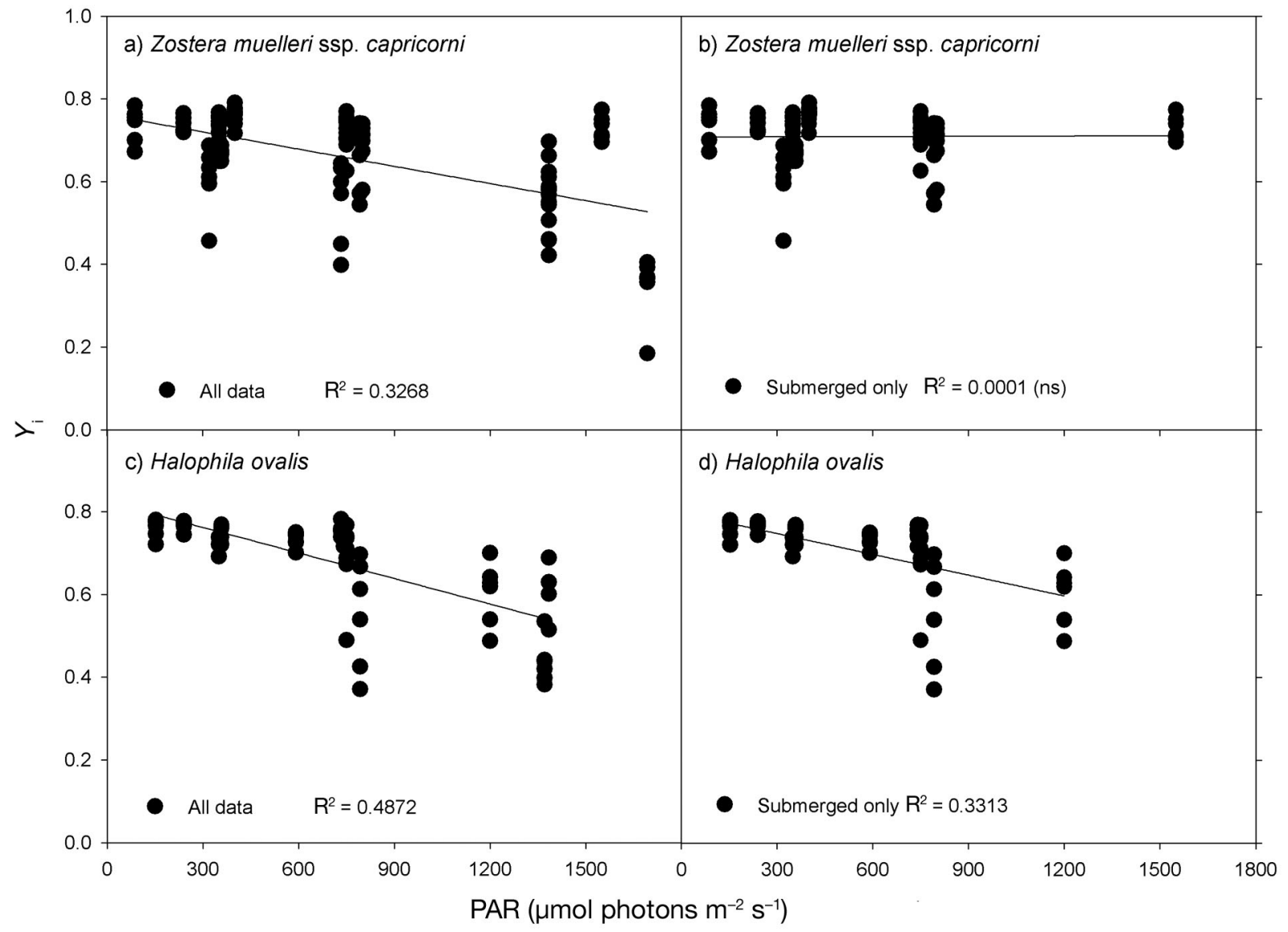

Fig. 5. Zostera muelleri ssp. capricorni and Halophila ovalis. Initial effective quantum yield $\left(Y_{\mathrm{i}}\right)$ as a function of in situ irradiance for $(\mathrm{a}, \mathrm{c})$ all data (submerged and air-exposed) collected during a tidal cycle and (b,d) yield obtained during submersion only. Dots represent all data collected from each field study (all 4 seasons). The relationships between $Y_{\mathrm{i}}$ and irradiance were fitted using linear regression (solid line). ns: not significant ( $p \geq 0.05$ )

air exposure during the growing season. This compliments the chl a fluorescence data, which further shows that during exposure, photosynthetic activity $\left(Y_{\mathrm{i},} r\right.$ ETRmax) declined as a result of increased photoinhibitory stress (increased de-epoxidation of violaxanthin). The increase in photosynthetic activity with increased irradiance in spring and summer (growing season) is consistent with previous studies that have found photoinhibition to be primarily absent in intertidal seagrasses (Beer \& Björk 2000). The cause of the photosynthetic stress measured in this study during air exposure is still unknown; it could have been the result of desiccation or excess heat or a combination of both. What is clear is that air exposure during a tidal cycle did not provide these intertidal seagrass meadows with a 'window' of opportunity in which to maximise productivity.

The significant and seasonally consistent decline in $Y_{\mathrm{i}}$ during air exposure for Zostera muelleri ssp. capricorni highlights the sensitivity of this intertidal spe- cies to exposed conditions. Light had very little effect on photosynthetic activity until it was combined with the negative effect of air exposure, in all seasons. $Z$. muelleri ssp. capricorni has been shown to have a preference for higher irradiances, with significant declines in carbon production and above-ground biomass when grown in light levels that are below saturating irradiances (Collier et al. 2011). This has major implications with respect to daily productivity, as during low tide (when irradiance is maximal), photosynthetic activity declines in response to exposure stress and not high irradiance, thus limiting the 'window' for high rates of productivity to times of high irradiance with submergence. Although this response was also seen in Halophila ovalis, it was only observed when it corresponded with high irradiances and was rarely significantly different from the high irradiance response. Indeed, in this study $H$. ovalis showed a stronger response to light condition than to exposure. This absence of any correlation between $Y_{\mathrm{i}}$ 
and air exposure for $H$. ovalis could be a result of its morphology. The leaf stems are fine and unable to support the leaves when the tide recedes, resulting in the leaves lying flat against the substrate and often submerged in small pools of water, potentially providing protection against air exposure (Björk et al. 1999).

For each season, measurements were taken close to midday low tide 'windows' when light levels were greatest. Cayabyab \& Enríquez (2007) found a strong light-dependent response in oxygen evolution rates in Thalassia testudinum with very similar values to those found in this study (ranging from 0.5 to $2.0 \mu \mathrm{mol} \mathrm{O}_{2} \mathrm{~cm}^{-2} \mathrm{~h}^{-1}$ over 50 to $2000 \mu \mathrm{mol}$ photons $\mathrm{m}^{-2} \mathrm{~s}^{-1}$ ). The increase in photosynthetic activity with increased irradiance in the spring and summer studies (growing season) would suggest that these species have a higher light requirement for growth and photosynthesis than what is normally available during high tide. It also suggests that they take advantage of increased irradiances as the tide recedes. However, during autumn and winter (senescent season) this type of opportunistic response by seagrasses is no longer apparent (Lee et al. 2007). The fact that $a^{*}(\lambda)$ remained largely constant throughout the tidal exposure events across all seasons, as well as the lack of change in leaf chlorophyll concentrations, confirms that these seagrass species do not regulate light-capturing efficiency under rapidly changing irradiance. Furthermore, an $a^{*}(\lambda)$ of approx. 0.5 is consistent with the average values published by Campbell et al. (2007) for intertidal H. ovalis (0.52 \pm $0.10)$ and $Z$. muelleri spp. capricorni $(0.60 \pm 0.04)$ sampled along the northern Queensland coast.

Comparison of the data between seasons shows the greatest response to air exposure for Zostera muelleri ssp. capricorni in the spring sampling month - i.e. a reduced response to exposure in late summer and the senescent seasons. This difference in stress during air exposure between the seasons could correspond to temperature differences or monthly light supply, both of which might play a significant role in the loss of photosynthetic efficiency in $Z$. muelleri ssp. capricorni. Water temperatures were more than $5^{\circ} \mathrm{C}$ warmer during the growing season $\left(23.7\right.$ to $\left.27.3^{\circ} \mathrm{C}\right) \mathrm{com}$ pared with the senescent season $\left(18.2\right.$ to $\left.21.5^{\circ} \mathrm{C}\right)$. Indeed, a recent study on $Z$. muelleri ssp. capricorni showed significant decline in photosynthesis, growth and carbon production at temperatures exceeding $31^{\circ} \mathrm{C}$ (Collier et al. 2011). The clear difference between spring and the other seasons is likely to be the result of a number of factors, rather than temperature alone. Average monthly irradiance varied from rela- tively high in spring (12.3 mol photons $\left.\mathrm{m}^{-2} \mathrm{~d}^{-1}\right)$ to around half of that in summer $\left(6.5 \mathrm{~mol}\right.$ photons $\mathrm{m}^{-2}$ $\mathrm{d}^{-1}$ ) and autumn (5.7 mol photons $\left.\mathrm{m}^{-2} \mathrm{~d}^{-1}\right)$, before

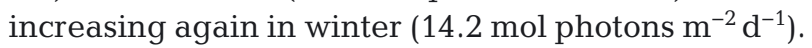
This would suggest a potential synergistic effect between light and temperature, where spring showed combined high light and warmer temperature conditions. A similar result was found by Collier et al. (2011) whereby high light in the presence of warmer temperatures led to reduced photosynthesis after 30 days, whereas high irradiance in the absence of high temperature showed no change in leaf photosynthesis. This provides a possible explanation for the difference in stress response measured between the spring and summer (growing season) in this study. However, determination of the exact causality of these differences is beyond the scope of this study.

Similarly, the measured decline in $Y_{\mathrm{i}}$ in response to high midday irradiances indicates that energy is being diverted from photochemistry to non-photochemical processes; this potentially results in substantial losses (up to $10 \%$ ) in carbon assimilation (Long et al. 1994). Again, this could relate to the warmer temperatures during the growing season (October and January), which showed higher respiration rates, potentially inhibiting carbon production (Bulthuis 1983, Ralph 1998). These seasonal differences in physiological stress responses measured in this study (increased respiration rates and decline in effective quantum yield) would again suggest that temperature might play a key role in the decrease in productivity during air exposure. One study found that in the absence of desiccation, high temperatures had a minimal effect on seagrass health and physiology, but when exposed to high temperatures during air exposure, there was a significant decline in seagrass photosynthetic health (Seddon \& Cheshire 2001).

Zostera muelleri ssp. capricorni and Halophila ovalis showed maximum de-epoxidation ratios during the growing season (max. approx. 0.6) declining in the senescent season (max. approx. 0.35). These maximum de-epoxidation ratios are within the same range (0.4 to 0.7 ) of those measured previously in Zostera marina (Ralph et al. 2002). The photoprotective pigment response measured over each tidal cycle, where de-epoxidation ratio increased with increased irradiance, was to be expected. However, the additional increase in de-epoxidation ratio during exposure provides further support for increased physiological stress under air exposed conditions. In several instances, this response occurred irrespective of irradiance being lower during the exposure period 
than at other times in the day. Violaxanthin deepoxidation ratio is an indicator of non-photochemical quenching, a photoprotective response in which carotenoid pigments are utilised to dissipate excess photon energy as heat (Demmig-Adams \& Adams 1996). The light-dependent increase in deepoxidation ratio indicates increased heat dissipation from the light-harvesting antenna of PSII. However, when combined with the significant decline in $Y_{\mathrm{i}}$, this data provides strong evidence that under air-exposed conditions, less photon energy is being utilised for photochemistry and a larger proportion is being lost as heat, thus providing protection for the cell when electron transport and photosynthesis are compromised by the external environmental conditions.

The results of this study have successfully demonstrated that tidal exposure does not provide intertidal seagrass meadows with a 'window' of respite from high turbidity. Furthermore, this study has increased our understanding of in situ photosynthetic efficiency and measured changes in oxygen evolution and physiology as a result of changes in irradiance and water depth over a tidal cycle. The seasonal variability in the response of these 2 species to air exposure has provided a greater understanding of annual patterns in seagrass photosynthetic activity under natural tidal fluctuations, and has demonstrated the need for seagrass to have access to high light in turbid coastal environments during the early growing season when compared with the senescent season. This has important management implications when considering the impact of coastal development (such as dredging operations) in estuaries and harbours.

Acknowledgements. The authors thank Dr. V. Kumar and M. Zbinden for their assistance and support on this project. This project was funded by Queensland Gas Corporation, Gladstone Ports Corporation Limited and the Queensland Department of Agriculture Fisheries and Forestry and Australian Research Council grant (LP110200454) awarded to P.J.R and M.R.

\section{LITERATURE CITED}

ä Abal E, Dennison W (1996) Seagrass depth range and water quality in southern Moreton Bay, Queensland, Australia. Mar Freshw Res 47:763-771

ä Beer S, Björk M (2000) Measuring rates of photosynthesis of two tropical seagrasses by pulse amplitude modulated (PAM) fluorometry. Aquat Bot 66:69-76

ä Beer S, Rehnberg J (1997) The acquisition of inorganic carbon by the seagrass Zostera marina. Aquat Bot 56: $277-283$

ä Björk M, Uku J, Weil A, Beer S (1999) Photosynthetic toler- ances to desiccation of tropical intertidal seagrasses. Mar Ecol Prog Ser 191:121-126

Bulthuis DA (1983) Effects of temperature on the photosynthesis-irradiance curve of the Australian seagrass, Heterozostera tasmanica. Mar Biol Lett 4:47-57

ä Campbell S, McKenzie L, Kerville S, Bite J (2007) Patterns in tropical seagrass photosynthesis in relation to light, depth and habitat. Estuar Coast Shelf Sci 73:551-562

ä Cayabyab NM, Enríquez S (2007) Leaf photoacclimatory responses of the tropical seagrass Thalassia testudinum under mesocosm conditions: a mechanistic scaling-up study. New Phytol 176:108-123

Collier CJ, Uthicke S, Waycott M (2011) Thermal tolerance of two seagrass species at contrasting light levels: implications for future distribution in the Great Barrier Reef. Limnol Oceanogr 56:2200-2210

ä Demmig-Adams B, Adams WW (1996) Xanthophyll cycle and light stress in nature: uniform response to excess direct sunlight among higher plant species. Planta 198: 460-470

Dennison WC, Orth RJ, Moore KA, Stevenson JC and others (1993) Assessing water quality with submerged aquatic vegetation. Bioscience 43:86-94

ä Duarte CM (1991) Seagrass depth limited. Aquat Bot 40: 363-377

ä Durako MJ (2007) Leaf optical properties and photosynthetic leaf absorptances in several Australian seagrasses. Aquat Bot 87:83-89

ä Enríquez S (2005) Light absorption efficiency and the package effect in the leaves of the seagrass Thalassia testudinum. Mar Ecol Prog Ser 289:141-150

Jeffrey SW, Humphrey GF (1975) New spectrophotometric equations for determining chlorophyll $a, b, c 1$, and $c 2$ in higher plants and natural phytoplankton. Biochem Physiol Pflanz 165:191-194

ä Johnston AM, Raven JA (1986) The analysis of photosynthesis in air and water of Ascophyllum nodosum L. Jol. Oecologia 69:288-295

ä Lee KS, Park SR, Kim YK (2007) Effects of irradiance, temperature, and nutrients on growth dynamics of seagrasses: a review. J Exp Mar Biol Ecol 350:144-175

ä Leuschner C, Landwehr S, Mehlig U (1998) Limitation of carbon assimilation of intertidal Zostera noltii and Z. marina by desiccation at low tide. Aquat Bot 62:171-176

ä Long SP, Humphries S, Falkowski PG (1994) Photoinhibition of Photosynthesis in Nature. Annu Rev Plant Physiol Plant Mol Biol 45:633-662

ä Longstaff B, Dennison W (1999) Seagrass survival during pulsed turbidity events: the effects of light deprication on the seagrasses Halodule pinifolia and Halophila ovalis. Aquat Bot 65:105-121

ä Orth RJ, Carruthers TJB, Dennison WC, Duarte CM and others (2006) A global crisis for seagrass ecosystems. Bioscience 56:987-996

ä Ralph PJ (1998) Photosynthetic response of laboratorycultured Halophila ovalis to thermal stress. Mar Ecol Prog Ser 171:123-130

ä Ralph PJ, Gademann R (2005) Rapid light curves: a powerful tool to assess photosynthetic activity. Aquat Bot 82: 222-237

ä Ralph P, Polk S, Moore K, Orth R, Smith W Jr (2002) Operation of the xanthophyll cycle in the seagrass Zostera marina in response to variable irradiance. J Exp Mar Biol Ecol 271:189-207

Ralph PJ, Durako MJ, Enríquez S, Collier CJ, Doblin MA 
(2007) Impact of light limitation on seagrasses. J Exp Mar Biol Ecol 350:176-193

ä Rasheed MA, Unsworth RKF (2011) Long-term climateassociated dynamics of a tropical seagrass meadow: implications for the future. Mar Ecol Prog Ser 422:93-103

ä Rasheed MA, Dew KR, McKenzie LJ, Coles RG, Kerville SP, Campbell SJ (2008) Productivity, carbon assimilation and intra-annual change in tropical reef platform seagrass communities of the Torres Strait, north-eastern Australia. Cont Shelf Res 28:2292-2304

ä Seddon S, Cheshire AC (2001) Photosynthetic response of Amphibolis antarctica and Posidonia australis to temperature and desiccation using chlorophyll fluorescence. Mar Ecol Prog Ser 220:119-130

ä Taylor HA, Rasheed MA (2011) Impacts of a fuel oil spill on seagrass meadows in a subtropical port, Gladstone,

Editorial responsibility: Morten Pedersen, Roskilde, Denmark
Australia - the value of long-term marine habitat monitoring in high risk areas. Mar Pollut Bull 63:431-437

ä Thayer SS, Björkman O (1990) Leaf xanthophyll content and composition in sun and shade determined by HPLC. Photosynth Res 23:331-343

ä Unsworth RKF, Cullen LC (2010) Recognising the necessity for Indo-Pacific seagrass conservation. Conserv Lett 3: 63-73

ä Van Heukelem L, Thomas C (2001) Computer-assisted highperformance liquid chromatography method development with applications to the isolation and analysis of phytoplankton pigments. J Chromatogr A 910:31-49

ä Zimmerman RC, Reguzzoni JL, Wyllie-Echeverria S, Josselyn M, Alberte RS (1991) Assessment of environmental suitability for growth of Zostera marina L. (eelgrass) in San Francisco Bay. Aquat Bot 39:353-366

Submitted: May 21, 2012; Accepted: December 17, 2012 Proofs received from author(s): April 6, 2013 